\title{
Novos Ramos de Graciliano - três inéditos do autor de Vidas secas
}

[ New Branches of Graciliano - Three unpublished texts by the author of "Vidas secas"

Thiago Mio Salla ${ }^{\mathrm{I}}$

SALLA, Thiago Mio. Novos Ramos de Graciliano - três inéditos do autor de Vidas secas. Revista do Instituto de Estudos Brasileiros, Brasil, n. 66, p. 25I-270, abr. 2017.

DOI: http://dx.doi.org/Io.II606/issn.23I6-90IX.voi66p25I-270

I Universidade de São Paulo (USP, São Paulo, SP, Brasil). 
Na obra memorialística Graciliano: retrato fragmentado, Ricardo Ramos se revelava um tanto quanto surpreso ao diagnosticar que, por mais que a obra de seu pai tivesse sido alvo até então de pesquisas febris, as quais, ao longo dos anos, desenterraram "crônicas, poesias, toda a obra juvenil e imatura de Graciliano, alcançando pseudônimos [...] secretos"2 , ninguém houvesse conferido atenção aos textos do autor de Vidas secas estampados em periódicos comunistas ou que estavam na órbita de influência do PCB. Quase a totalidade dessa produção, até há pouco tempo inédita em livro, ganhou espaço na obra Garranchos (20I2). Todavia, na recolha do material que compôs tal volume, alguns textos ficaram pelo caminho e, agora, puderam ser, enfim, recuperados, tendo em vista a ampliação das pesquisas feitas inicialmente. Trata-se das crônicas "O melhor dos mundos" e "Coisas da China", além do telegrama "O atentado contra o escritor Wladimir Guimarães", publicados em diferentes veículos de orientação esquerdista entre I945 e I95I, isto é, na porção final da vida do romancista alagoano3.

\section{O MELHOR DOS MUNDOS}

Considerando-se tais aspectos, inicia-se esta pequena seleta de textos inéditos em livro de Graciliano com o escrito "O melhor dos mundos", produção que, em I5 de agosto de I945, ganhou as páginas do jornal A Manha, dirigido pelo Barão de Itararé (Aparício Torelly). Nesse momento, Graciliano estava em vias de entrar oficialmente no então Partido Comunista do Brasil - PCB, gesto que se realiza, de fato, três dias depois, quando o próprio Luís Carlos Prestes, na época secretário-geral do partido, assina a ficha de inscrição do escritor alagoano ${ }^{4}$. Tal dado indica que a publicação do texto em questão no referido hebdomadário pode ser enquadrada num contexto mais amplo de aproximação de Graciliano, que desde longa data mostrava afinidade com

2 RAMOS, Ricardo. Graciliano: retrato fragmentado. São Paulo: Siciliano, I992, p. I4O.

3 Como se sabe, Graciliano Ramos faleceu em 20 de março de I953.

4 GRACILIANO Ramos ingressa no Partido Comunista do Brasil e participa da luta pela Constituinte. Tribuna Popular, Rio de Janeiro, I8 ago. I945, p. I-2. 
o ideário de esquerda, com o PCB. Não que A Manha fosse um jornal formalmente vinculado ao Partidão, mas as "ideias comunistas” do Barão de Itararé havia muito já eram conhecidas no meio intelectual e entre as autoridades policiais.

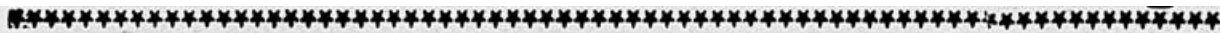

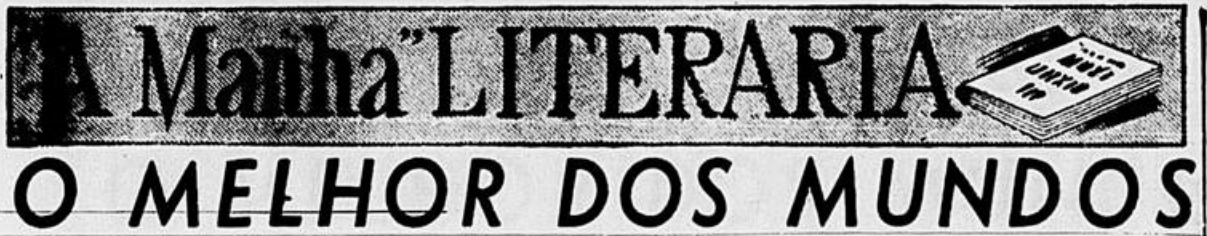

Neste mundo só houve um serw. S realmente digno de ser ou5 com algum interesse. Mas inmente foi proferido hd vaios stculos. Mesmo desse nos licramos.

…

Botá nos livros, o Sermáo da Thanha - local, aliás, de boa tictica, de modo geral. $\boldsymbol{E} 0$ orais disse: " $E$ ' mais facll $\mathrm{wm} \mathrm{ca}$ to passar pelo jundo de uma 5. va que um rico pemetrar no o dos céus."

Fid em diante, os ricos comeganom a ficar um pouco alarMuto mais que os cameLin por sinal náo leram nein ontram o sermão.

$\bullet *$

- reino dos cétus tornou-se o poino ideal para a última acooritera gente, que ráo vive direito 3 pensando nas dificuldades de Somodação aqui por baixo.

$\rightarrow *$

Em vista disso tudo, surgiram

trases famosas: "Meu reino wo cavalo"; "Meu reino por
Graciliano RAMOS (Para A MANHA)

uma cozinheira"; "Nâo há vatapá sem pimenta do reino"; "A Historia é feita com ordenaçōcs do reino": "Meu reino por um apartamento".

o reino de que falam deve ter amplas instalaçóes, luz indiretu, agua abundante, jardim na frente, refrigeraça perfeita. Mas que luvas nä deveräo exigir hoje um dia pelas chaves desse reino? $\bullet \bullet$

Lembrei-me agora do romancista Cronin, o tal de "A Cidadela, que nos contou a longa historia de "As Chaves do Relno". Pode-se ler o romance, na. edicūo da Livraria José Olimpio, ou assistir o filme. Da minha

\section{O MELHOR MÉDICO}

- melhor médico é aquele que se procura e não se encontra. (Diderot). parte, aconselho a leitura, embora de mais trabalho.

No romance $h a ́$ um missionario que é uma grande figura, com uma vida extraordinaria. $E^{\prime}$ um ttpo admiravel, qua, apesar da sua situação, não se aprovelta disso para fazer qualquer sermáo contra o leitor incauto. $E$ isso é uma vantagem enorme.

$$
\bullet \bullet
$$

Com um bom romance, como este, podemo-nos sentir no methor dos mundos. Contudo, devo esclarecer que o melhor dos mundos náo vale um caracol.

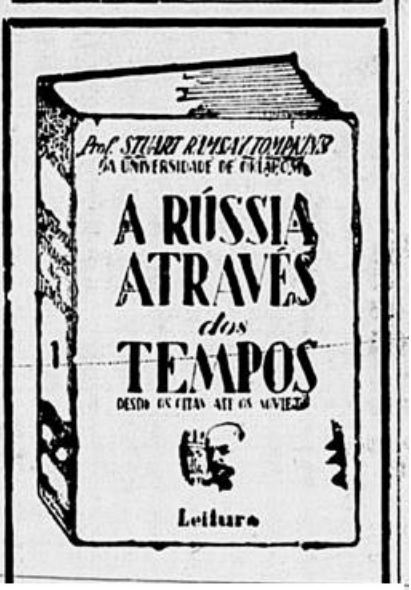

Figura I - Crônica “O melhor dos mundos”, publicada no jornal A Manha, do Barão de Itararé, em I5 de agosto de I945. Fundação Biblioteca Nacional, Rio de Janeiro

Por sinal, ele e Graciliano tornaram-se amigos no momento em que ambos se 
encontravam presos nos porões da ditadura varguista, sem acusação formal5, por supostas atividades subversivas relacionadas à Intentona de I935 promovida pela Aliança Nacional Libertadora - ANL. Nas páginas de suas Memórias do cárcere, o artista alagoano refere-se a Apporelly (alcunha pela qual era mais conhecido Aparício Torelly) em diversas oportunidades. Conheceram-se, de fato ${ }^{6}$, no banheiro do Pavilhão dos Primários, anexo da Casa de Correção do Rio de Janeiro, e logo firmaram amizade:

Saí. E enquanto me enxugava, conheci Apporelly, nu, um sujeito baixo, de longa barba grisalha, o nariz arrebitado, que uma autocaricatura vulgarizou. Vestimo-nos, subimos para o banho de sol. Algumas dezenas de homens faziam ginástica. Fomos sentar-nos longe do exercício, prudentes e capengas, ele hemiplégico, eu com a perna entorpecida, mal me equilibrando, pontadas constantes no lugar da operação. A viagem a bordo me arrasara. Talvez essa coincidência no desarranjo físico nos tenha aproximado. Familiarizamo-nos depressa. Confiou-me Apporelly o plano de um trabalho concebido ultimamente, ia dedicar a ele os ócios da prisão. Tencionava compor a biografia do Barão de Itararé?.

Ao longo do período em que ficaram encarcerados (depois do Pavilhão dos Primários, voltaram a conviver na Sala da Capela da Casa de Correção ${ }^{8}$ ), Graciliano insiste em saber sobre o andamento das memórias do Barão de Itararé. Todavia, Apporelly não se resolvia a iniciar o trabalho e apenas "exibia fragmentos já lançados

5 Conforme o prontuário de Graciliano na Polícia Política, documento de número II.473, presente no Arquivo Público do Estado do Rio de Janeiro, o escritor teria sido demitido de seu cargo de diretor de Instrução Pública do Estado de Alagoas "em virtude de suas atividades subversivas", em março de I936. Ainda nesse mesmo mês foi preso, sob a acusação de ter participado "do movimento comunista irrompido no Nordeste do país, em 23.II.I935". Porém, como sublinha Moraes, "jamais seria processado ou acusado publicamente de algum deslize”. MORAES, Dênis de. O velho Graça: uma biografia de Graciliano Ramos. São Paulo: Boitempo, 20I2, p. II5.

6 Antes desse encontro, Graciliano relata os risos que irromperam do primeiro pronunciamento de Apporelly na "Rádio Libertadora", espécie de estação de rádio improvisada pelos detentos que veiculava "notícias de jornais, comentários, acerbas críticas ao governo”. RAMOS, Graciliano. Memórias do cárcere. 4 v. Rio de Janeiro: José Olympio, v. 2, I953, p. 20.

7 Ibidem, p. 48.

8 Nesse segundo convívio, Graciliano alojou-se numa cama ao lado de Apporelly. Durante as noites, quando este passava mal, aquele abandonava o travesseiro, agarrava o doente até que ele se acalmasse. "Atormentava-me. Iria Apporelly morrer-me nos braços? Por fim o meu ato era mecânico: ao despertar, já me achava seguro a ele, tentando um socorro impossível”. Ibidem, v. 4, p. Iro. 
no hebdomadário" . De fato, a obra em questão nunca chegou a ser feita ${ }^{\mathrm{Io}}$, mas, pouco depois de ser liberado, Apporelly tornava a lançar o jornal A Manha, em cujo primeiro plano avultava a figura do barão, criada pelo humorista um ano após a Revolução de $1930^{\text {II }}$.

Portadora do subtítulo sugestivo “Órgão de ataques... de riso", A Manha começara a circular em I3 de maio de I926. Sua publicação foi interrompida em 26 de outubro de 1935 em decorrência da referida prisão de Aporelly. Com a soltura dele, o hebdomadário voltou a circular por um curto período entre 6 de maio e 3 de junho de I937 e retornou tão somente, de modo efetivo, em 27 de abril de I945. É nessa nova fase do periódico que se insere a produção inédita em livro de Graciliano apresentada logo a seguir.

Antes mesmo de tal escrito vir à tona, em curta nota informativa, A Manha já se referia de modo irônico e chistoso a Graciliano, como "nosso auxiliar de redação [...], que também é um romancista festejado, autor de Angústia, Vidas secas, São Bernardo e outras biografias de santos" ${ }^{\text {"I }}$. Nesse texto, registra-se ainda que o escritor alagoano supostamente viajaria ao Chile por motivo de intercâmbio cultural a mando de Sérgio Buarque de Holanda, então presidente nacional da Associação Brasileira de Escritores (ABDE). Tal partida para o estrangeiro (que, de fato, nunca ocorreu) representaria uma perda para o jornal, pois Graciliano viria a assumir a coluna de mundanismo de A Manha, "onde serão assinalados todos os acontecimentos no mundo do nosso grã-finismo, com descrição de vestidos e chapéus de nossas rainhas da elegância"ז3.

Evidentemente que o discreto e casmurro autor de Vidas secas não chegou a exercer a função de cronista mundano de A Manha. Na verdade, "O melhor dos mundos", sua única crônica estampada em tal publicação, figurou na seção "A Manha Literária", destinada ao "registro sereno e imparcial das coisas literárias" ${ }^{4}$. Essa espécie

9 Ibidem, v. 2, p. 49.

Io O mais perto que Aporelly chegou de produzir uma biografia a respeito do Barão de Itararé deu-se, nos anos I950, quando ele produziu um texto a respeito de seu pseudônimo para um de seus almanaques. FIGUEIREDO, Cláudio. Entre sem bater: a vida de Apparício Torelly, o Barão de Itararé. Rio de Janeiro: Casa da Palavra, 20I2, p. 263.

II "Em outubro de I930, as forças reunidas em torno da Aliança Liberal se sublevaram, sob a liderança de Getúlio Vargas. A batalha decisiva deveria se travar em Itararé, mas não chegou a ocorrer, porque Washington Luís foi deposto por seus auxiliares. [...] Um ano após a 'revolução' vitoriosa, o humorista se concedeu o título de 'Duque de Itararé', anunciando em seu jornal que a concessão estava sendo feita a uma 'personalidade de excepcional valor, que se distinguiu no campo de batalha'. Algumas semanas depois, rebaixou seu título para Barão de Itararé, 'como prova de modéstia”'. KONDER, Leandro. Barão de Itararé. São Paulo: Brasiliense, I983, p. I7-I8.

I2 NO MUNDO da Elegância - Uma nova seção de A Manha será confiada ao nosso companheiro Graciliano Ramos, assim que este regresse de uma viagem ao Chile. A Manha, Rio de Janeiro, 24 maio I945, p. 2.

I3 Ibidem.

I4 A MANHA Literária. A Manha, Rio de Janeiro, Io maio I945, p. 4. 
de "rodapé", que seria publicado em pé, e não deitado's, contou com colaborações esporádicas de outros nomes representativos da intelectualidade brasileira, tais como Álvaro Lins, Manuel Bandeira, Tristão de Ataíde e Sérgio Buarque “dos Países Baixos”. Em linhas gerais, nesse espaço voltado à crítica ligeira e bem-humorada, cada resenhista fazia comentários pontuais a um livro recém-lançado. O próprio poeta de Libertinagem, por exemplo, louvou, em agosto de I945, o aparecimento de Infância, memórias em que Graciliano, "com aquele jeito de urubu, teve coragem de contar tanta coisa incrível da sua própria vida numa obra que se destina a ficar para sempre na literatura brasileira"16.

Em “O melhor dos mundos", por sua vez, Graciliano exercita seu humor ferino com relação à religião ao fazer referência a uma das passagens mais conhecidas do Novo Testamento: o Sermão da Montanha. A remissão motejadora a tal prédica serve de mote para o escritor alagoano tratar de As chaves do reino, romance do best-seller Archibald Joseph Cronin, publicado pela José Olympio em I942, cuja adaptação para o cinema estava em vias de estrear nos cinemas brasileiros em meados de I945. Nesse livro, o padre escocês Francis Chisholm é enviado à China em missão religiosa, mas seu trabalho de catequização fica em segundo plano ante a luta que passa a desempenhar, por lá, contra a fome, a guerra civil e outros problemas sociais. Mais do que se ater às supostas qualidades literárias da obra, Graciliano louva o fato de o protagonista da história em questão não se valer de sua condição de missionário para investir em pregações religiosas. E, livre desse tipo de doutrinação, o leitor do romance teria a oportunidade de, em lugar do custoso "reino dos céus", transportar-se para o melhor dos mundos proporcionado pela ficção, o qual, todavia, segundo a perspectiva desmistificadora do autor alagoano, também valeria pouco ou quase nada ${ }^{\text {T7 }}$.

\section{Coisas da China}

Ao lado desse Graciliano satírico, avulta também, já ao final dos anos I940, um escritor mais afinado ao $\mathrm{PCB}$, que não deixa de comentar, no calor da hora, um evento que causou surpresa e euforia entre os comunistas brasileiros: a vitória da revolução

I5 “O nosso rodapé, como o nome indica, sairá em pé, o que já constitui uma inovação. Insistem certos órgãos da imprensa em colocar os imensos artigos dos seus críticos numa posição indigna: deitados. Ora, deitado ninguém trabalha, e os críticos, por isso, não escrevem com regularidade...”. Ibidem.

I6 BANDEIRA, Manuel. Memórias de um romancista. A Manha, Rio de Janeiro, 23 ago. I945, p. 9.

I7 Ainda com relação à faceta de Graciliano Ramos como humorista, o Barão de Itararé fez estampar nas páginas de A Manha o epigrama "A um sifilítico", publicado pelo escritor alagoano anteriormente no jornal O Índio, de Palmeira dos Índios, sob o pseudônimo Anastácio Anacleto: "De sífilis terciária um dia, enfim, morreu/ Este de alcoide imundo ignóbil filho espúrio;/ E a terra que o comeu/ Entrou logo a tomar injeções de mercúrio”. RAMOS, Graciliano. A um sifilítico. A Manha, Rio de Janeiro, 5 set. I945, p. Io. Cf. ANACLETO, Anastácio [Graciliano Ramos]. Factos e Fitas [III]. In: RAMOS, Graciliano. Garranchos - textos inéditos de Graciliano Ramos. Organização de Thiago Mio Salla. Rio de Janeiro: Record, 20I2, p. 87. 
chinesa ${ }^{18}$. Em vista disso, o texto "Coisas da China", o segundo a compor a coletânea ora apresentada, foi estampado no jornal esquerdista Voz Operária em I6 de junho de I949. Nesse momento, tal folha passava a ser o órgão central do PCB em substituição à Classe Operária, periódico suspenso e depois fechado pelas forças policiais em maio de I949.

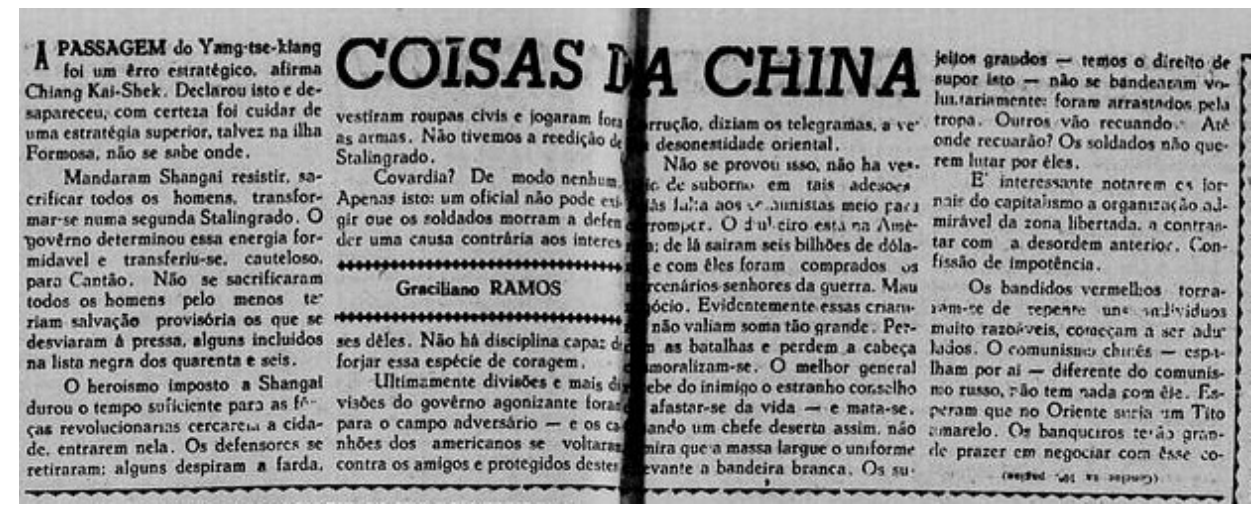

Figura 2 - Crônica "Coisas da China”, estampada no periódico do PCB Voz Operária, em I6 de junho de I949. Fundação Biblioteca Nacional, Rio de Janeiro

Em linhas gerais, Voz Operária apresentava em suas páginas as principais teses do partido, bem como trazia notícias relativas às condições de vida dos trabalhadores, ao movimento comunista e às mobilizações operárias tanto no Brasil quanto em outras partes do mundo ${ }^{\text {I9 }}$. Não por acaso, desde seu aparecimento no início de I949, o periódico acompanha e avalia os expressivos avanços do Exército Vermelho em sua luta contra o Kuomintang, partido nacionalista chinês, que, liderado por Chiang Kai-shek, contava com o apoio das potências ocidentais ${ }^{20}$.

Para além de tal conteúdo estampado na folha comunista, na crônica "Coisas da China", Graciliano revela conhecer de perto os telegramas das agências internacionais que, republicados nos mais diferentes jornais cariocas (Correio da Manhã, Diário de Notícias, A Manhã etc.), informavam sobre o desenrolar da luta entre comunistas e nacionalistas na China. De modo geral, critica a parcialidade de determinadas abordagens e certos lugares-comuns presentes na cobertura

I8 AARÃO REIS, Daniel. O maoismo e a trajetória dos marxistas brasileiros. In: MORAES, João Quartim; AARÃO REIS, Daniel (Org.). História do marxismo no Brasil. V. I: O impacto das revoluções. Campinas: Editora da Unicamp, 2007, p. I77.

I9 FERREIRA, Jorge. Os comunistas e os novos rumos. In: SIMPÓSIO NACIONAL DE HISTÓRIA, 26., 20II, São Paulo. Anais... Organização de Marieta de Moraes Ferreira. São Paulo: ANPUH, jul. 20II. Disponível em: <http://www.snh20II.anpuh.org/resources/anais/I4/I3003III93_ARQUIVO_OscomunistaseosNovosRumos. pdf $>$. Acesso em: 27 jan. 2017.

20 Cf. NORMALIZOU-SE rapidamente a vida em Xangai. Voz Operária, Rio de Janeiro, 7 jun. I949, p. 4; CACHIN, Marcel. Mudará a face do mundo. Voz Operária, Rio de Janeiro, 7 jun. I949, p. 5; O EXEMPLO da China frutifica em toda a Ásia Sul-Oriental. Voz Operária, Rio de Janeiro, I5 jul. 1949, p. 6. 
realizada, sobretudo no que dizia respeito ao suposto fato de os comunistas estarem subornando as divisões militares do governo agonizante, numa clara mostra da "velha desonestidade oriental".

Ao lançar mão de tal questionamento à imprensa dita capitalista, Graciliano realiza movimento textual análogo ao visto em suas crônicas "Reviravoltas" ${ }^{2 \mathrm{I}} \mathrm{e}$ "Revolução Russa" ${ }^{22}$, nas quais, em perspectiva memorialística, põe-se a tratar da revolução de outubro de I9I7. Em ambas, refere-se a deturpações, mentiras e calúnias que teriam marcado a cobertura jornalística relativa à vitória dos bolcheviques e, posteriormente, ao governo por eles instituído. Em vista de tal campanha propagandística negativa, fazia-se necessário decifrar as informações recebidas, ler nas entrelinhas, em meio a exageros e omissões ${ }^{23}$. O caso chinês se mostraria semelhante, com a diferença de que, agora, o escritor alagoano não apenas procuraria desvendar e contornar, como leitor, os equívocos veiculados, mas, como artista consagrado, explicitá-los nas páginas do jornal que exercia a função de porta-voz do PCB.

Nesse processo de crítica à imprensa, Graciliano também atenta, não sem ironia, para uma aparente virada midiática no modo como eram tratados os "bandidos vermelhos chineses”, tornados de repente em "indivíduos muito razoáveis”. Tal mudança atrelava-se à percepção alardeada por jornais e revistas de que já começariam a se cristalizar diferenças entre o comunismo russo e o comunismo chinês, e, por conseguinte, cresciam as expectativas de que a China passaria a ser governada por um suposto “Tito amarelo", isto é, por um líder que, na defesa dos interesses nacionais, manifestaria independência em relação a Moscou, de modo análogo a Josip Broz Tito, comandante da então Iugoslávia. Segundo Graciliano, "os banqueiros terão grande prazer em negociar com esse comunismo de novo tipo". Tal comentário sarcástico, que procura pôr em relevo os reais interesses em torno da circunstancial mudança de postura dos Estados Unidos e da Inglaterra em relação à China, amplifica-se ao final do texto quando o autor de Angústia assinala que "provavelmente não será necessário o Pacto do Atlântico". Em outras palavras, sugere de modo mordaz que a aliança militar capitaneada por Washington não precisaria ser mobilizada em se tratando do país comandado por Mao, o qual, supostamente, não se submeteria à União Soviética e estaria disposto a receber capitais norte-americanos.

Se, tendo em vista o momento no qual Graciliano estava inserido, suas afirmações transcritas acima devem ser lidas em chave irônica (em I4 de outubro de I950, Mao e Stálin, apesar de já se tornarem patentes algumas divergências entre eles, assinam um tratado de amizade, aliança e assistência mútua, enquanto, por outro lado, os Estados Unidos promovem um bloqueio econômico, político e militar à China e, em seguida, desencadeiam a guerra da Coreia), sendo interessante notar que, quando se extrapola anacronicamente esse contexto imediato pressuposto pelo autor, tais palavras soam como uma espécie de vaticínio em relação aos desdobramentos vindouros da China pós-revolução.

2I RAMOS, Graciliano. Reviravoltas. In: Linhas tortas. 2I. ed. Rio de Janeiro: Record, 2005, p. 328-33I.

22 RAMOS, Graciliano. Revolução Russa. In: . Garranchos..., 2012, op. cit., p. 24I-243.

23 Ibidem, p. 24I. 


\section{EM DEFESA DOS ESCRITORES}

No primeiro semestre de I95I, depois de algumas recusas, o Graciliano Ramos militante disciplinado aceita uma espinhosa missão que lhe fora confiada pela direção do PCB: presidir a Associação Brasileira de Escritores (ABDE). Depois da "pendenga" ocorrida nas eleições da instituição de I949, que resultou na debandada de grande contingente de intelectuais e fez com que a entidade fosse instrumentalizada pelos comunistas, o nome do artista alagoano avultava como capaz de manter a ABDE de pé $^{24}$ e contornar, minimamente, o isolamento e a falta de representatividade a que o radicalismo do partidão a tinha submetido.

$\mathrm{O}$ autor de Vidas secas assume como presidente da ABDE em I5 de maio de I95I, depois de uma eleição que não passara de pura formalidade, pois a entidade se reduzira a uma simples facção subordinada ao $\mathrm{PCB}^{25}$ e havia apenas a chapa de Graciliano concorrendo ao pleito. Em seu discurso de posse, além de fazer um balanço relativo à perda de inúmeros sócios e de responder a certas críticas endereçadas à instituição, destaca que um dos objetivos de sua gestão seria a melhora das "condições dos literatos" no que dizia respeito aos direitos autorais, ao aumento das tiragens e à defesa e à divulgação do livro nacional ${ }^{26}$. Ao mesmo tempo, procurou atrair novamente os artistas que se afastaram da entidade e se engajou na realização do IV Congresso Brasileiro de Escritores, ocorrido em Porto Alegre, em setembro de I95I.

Paralelamente, como presidente da ABDE, Graciliano procurou atuar pública e ativamente em prol da garantia das liberdades democráticas em questões relativas ao Brasil e a outros países. Para tanto, encabeçou manifestos, participou de diversas campanhas, bem como redigiu apelos, protestos, telegramas, cartas abertas endereçados a diferentes figuras públicas. Em conformidade com tal linha de ação, condena a guerra bacteriológica então desencadeada na Coreia e na China; posiciona-se contra a postura da recém-criada Sociedade Carioca de Escritores, que vedava a filiação de comunistas; em meio à campanha promovida pelo PCB em prol da paz mundial, manifesta seu apoio ao Congresso dos Povos pela Paz realizado em Viena em dezembro de I952; censura a condenação à prisão do escritor portenho Alfredo Varela; repudia a suspensão do professor e brasilianista argentino Norberto A. Frontini; e, de modo enfático, pede a libertação do escritor paraguaio Obdulio Barthe, que havia mais de dois anos se encontrava preso em péssimas condições ${ }^{27}$.

Embora o prestígio da ABDE ou mesmo do próprio Graciliano não fossem suficientes para atingir os nobres objetivos almejados, a chancela da entidade e a assinatura do autor permitiam que os documentos em questão, depois de remetidos

24 MORAES, Dênis de, op. cit., p. 267.

25 RAMOS, Ricardo, op. cit., p. I48.

26 RAMOS, Graciliano. Garranchos..., 20I2, op. cit., p. 3I6.

27 Cf. os seguintes textos de Graciliano recolhidos em Garranchos: "Condena a guerra bacteriológica a Associação Brasileira de Escritores” (p. 332-333), "Unidade em defesa dos direitos do escritor” (p. 334-336), “Apelo de Graciliano Ramos aos intelectuais brasileiros” (p. 337-338), “A ABDE e os atentados à cultura argentina” (p. 327-329) e “De Graciliano Ramos a Obdulio Barthe” (p. 339-340). GRACILIANO, Ramos. Garranchos..., 20I2, op. cit., p. 3 I6. 
a seus destinatários principais, reverberassem no maior número possível de publicações. "É aí que entra o papel das revistas e dos jornais próximos ao campo de esquerda: fazer circular um tipo de notícia que normalmente não encontraria lugar nos veículos da grande imprensa" ${ }^{28}$.

Entre tais materiais em que Graciliano procura intervir, encontra-se o breve texto que fecha essa coletânea, publicado em I6 de dezembro de I95I, no jornal Imprensa Popular, veículo do PCB voltado ao grande público que nasce em I948 para substituir a Tribuna Popular, órgão colocado na ilegalidade juntamente com o partido no ano anterior ${ }^{29}$. Nesse breve telegrama, Graciliano demanda ao governador da Bahia, Luís Régis Pacheco Pereira, referido como "responsável pela ordem pública garantidora do livre exercício dos direitos cívicos”, a punição dos culpados pelo atentado sofrido por Wladimir Guimarães, então secretário-geral do Movimento Baiano dos Partidários da Paz e diretor da revista de orientação comunista Seiva. Em frente à sua residência, Guimarães fora alvo de vários tiros de revólver disparados por um policial conhecido como torturador de presos políticos ${ }^{30}$. Mediante o chamamento da mais alta autoridade do Estado a punir um subordinado criminoso, mais do que tão somente se colocar na defesa de um associado da ABDE, Graciliano reafirma que apenas uma resposta dura do governo baiano a tal atentado poderia manter a crença na legalidade do Executivo, sobretudo quanto ao papel deste na "defesa patriótica de nosso patrimônio de riquezas naturais ou culturais".

28 BARBOSA, Juliana Monnerat. Militância política e produção literária no Brasil (dos anos 30 aos 50): as trajetórias de Graciliano Ramos e Jorge Amado e o PCB. 20I0, 403f. Tese (Doutorado em História). Universidade Federal Fluminense, Niterói, RJ, 20Io, p. 265.

29 CARNEIRO, Maria Luiza Tucci; KOSSOY, Boris (Org.). A imprensa confiscada pelo Deops: I924-I954. São Paulo: Ateliê Editorial; Imprensa Oficial do Estado de São Paulo; Arquivo do Estado, 2003, p. I44.

30 PROTESTOS contra a agressão ao dr. Wladimir Guimarães. Imprensa Popular, Rio de Janeiro, 5 dez. I95I, p. 2. 


\section{O Ateniado Contra}

\section{O Escritor \\ Wladimir Guimarãzs}

A diretoria da Assccinctio Brusileira de Earritores enviou $n$ segu nte telegrama ao governador da Rahia protes. turdo contra n stentado de que foi vitimn recentomente o eseritar Wladimir Guimarảes:

cContra a violîncia de que foi vituma o nusso tassocianto Wladimit Guimartus a Associaçă Brasileira de Bsertores protests perante V Bxcia, como responsável pela or- dem publiea earantidora to livre exercicin dis direitos ofvicos, morwente quandr se trata da defesa patrintica de nosso patrimumo de rimuenas natursis ou coltumis. A nunitis $n$ dos entosutos plo iten-

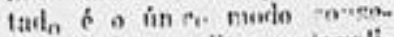

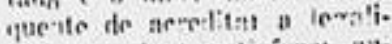

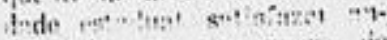
scius do patz 6 mrogress io brave pose hathiano

Pela Diretora

(As.) - Graciliano Kumon, presidentez.

Figura 3 - Telegrama "O atentado contra o escritor Wladimir Guimarães”, reproduzido no jornal Imprensa Popular em I6 de dezembro de I951. Fundação Biblioteca Nacional, Rio de Janeiro

$$
* * *
$$

Feita a breve apresentação e realizado o enquadramento dos escritos de Graciliano Ramos que compõem essa pequena coletânea, seguem os textos propriamente ditos, dispostos em ordem cronológica. Do ponto de vista editorial, na apresentação do material realizaram-se a atualização ortográfica dos escritos (segundo as normas correntes preconizadas pelo Acordo Ortográfico da Língua Portuguesa de I990); a solução ocasional de omissões e erros tipográficos; bem como a padronização de formatações especiais (negrito e itálico, sobretudo). Além disso, mantiveram-se os casos de pontuação de caráter mais estilístico. Investiu-se também na produção de notas de rodapé, tendo em vista a recomposição dos contextos socioculturais em que as composições foram originalmente publicadas e, por conseguinte, a aproximação delas dos leitores do autor de Vidas secas. 


\section{O MELHOR DOS MUNDOS ${ }^{31}$}

Neste mundo só houve um sermão realmente digno de ser ouvido com algum interesse. Mas [feliz]mente foi proferido há vários séculos. Mesmo desse nos livramos.

$$
* * *
$$

Está nos livros, o Sermão da Montanha - local, aliás, de boa acústica, de modo geral. E o orador disse: "É mais fácil um camelo passar pelo fundo de uma agulha que um rico penetrar no reino dos céus”32.

Daí em diante, os ricos começaram a ficar um pouco alarmados. Muito mais que os camelos, que por sinal não leram nem ouviram o sermão.

$$
* * *
$$

O reino dos céus tornou-se o [pouso] ideal para a última acomodação. E isso tem ajudado muita gente, que não vive direito só pensando nas dificuldades de acomodação aqui por baixo.

$$
* * *
$$

3I RAMOS, Graciliano. O melhor dos mundos. A Manha (do Barão de Itararé), Rio de Janeiro, I5 ago. I945, p. 7 .

32 Versão levemente modificada do versículo 24, do capítulo I9, do Evangelho de Mateus, presente na edição da Bíblia (feita pela Garnier na segunda metade do século XIX) que pertenceu a Graciliano Ramos: "Que mais fácil é passar um camelo pelo fundo de uma agulha do que entrar um rico no reino dos céus”. EVANGELHO de São Mateus, Português. In: Bíblia sagrada. Tradução de António Pereira de Figueiredo. Rio de Janeiro, B. L. Garnier, [I864], t. 2, cap. I9, vers. 24, p. 365. Variantes dessa mesma fala de Cristo ainda aparecem nos evangelhos de São Marcos (Io, 25) e Lucas (I8, 25). A Bíblia de Graciliano faz parte do acervo do Arquivo Graciliano Ramos do IEB/USP. Mais informações sobre ela podem ser encontradas em: SALLA, Thiago Mio. A Bíblia sagrada de Graciliano Ramos: a leitura e a glosa do texto religioso realizadas pelo autor de Vidas secas. Livro, São Paulo, Núcleo de Estudos do Livro e da Edição (ECA/USP), v. 4, 20I4, p. I4I-I67. Convém ainda assinalar que, tradicionalmente, a porção do Novo Testamento conhecida como "Sermão da Montanha" restringe-se ao intervalo entre os capítulos 5 e 7 do Evangelho de São Mateus (uma forma mais curta de tal pregação encontra-se também no sexto capítulo do Evangelho de São Lucas, entre os versículos 20 e 49). Assim, tal passagem não englobaria o ensinamento fundado na imagem metafórica da passagem de um "camelo no fundo de uma agulha”, preceito que ganha espaço tão somente no capítulo I9 do livro do referido apóstolo. Possivelmente, em chave metonímica, Graciliano aluda ao dito sermão como o conjunto do ministério de Jesus na Judeia. 
Em vista disso tudo, surgiram as frases famosas: "Meu reino por um cavalo"; "Meu reino por uma cozinheira”; “Não há vatapá sem pimenta do reino”; “A história é feita com ordenações do reino"; "Meu reino por um apartamento”33.

$$
* * *
$$

O reino de que falam deve ter amplas instalações, luz indireta, água abundante, jardim na frente, refrigeração perfeita. Mas que luvas não deverão exigir hoje em dia pelas chaves desse reino?

$$
* * *
$$

Lembrei-me agora do romancista Cronin, o tal de $A$ cidadela ${ }^{34}$, que nos contou a longa história de As chaves do reino ${ }^{35}$. Pode-se ler o romance, na edição da Livraria José Olympio, ou assistir ao filme ${ }^{36}$. Da minha parte, aconselho a leitura, embora dê mais trabalho.

33 Foram encontradas referências às duas frases que encabeçam tal lista apresentada por Graciliano. A primeira delas remonta ao quinto ato, quarta cena, do drama histórico Ricardo III, de William Shakespeare, no qual o sanguinário monarca que dá título à peça declara, depois de perder sua montaria no campo de batalha: "A horse! A horse! My kingdom for a horse". SHAKESPEARE, William. King Richard III. Edited by Antony Hammond. Londres, Nova York: Routledge, I990, p. 328. A segunda corresponde ao título da versão brasileira do filme My kingdom for a cook, comédia dirigida por Richard Wallace em I943 e que estreou nos cinemas cariocas em julho do ano seguinte. CINEMATOGRAFIA - "Meu reino por uma cozinheira”. Diário de Notícias, Rio de Janeiro, I8 jul. I944, p. II.

34 Referência ao romancista e médico escocês Archibald Joseph Cronin (I896-I98I), um dos maiores best-sellers internacionais do século XX. O romance A cidadela (I937), cuja edição brasileira feita pela José Olympio em I939 contou com prefácio e tradução de Genolino Amado, descreve a injustiça e a incompetência da prática médica da época, contribuindo para o estabelecimento do Serviço Nacional de Saúde na Grã-Bretanha. PEREIRA, José Mario (Org.). José Olympio - o editor e sua Casa. Rio de Janeiro: Sextante, 2008, p. 286. Curiosamente, Aparício Torelly assinala que teria abandonado a medicina, pois teria ocorrido com ela a mesma tragédia que se abateu sobre Cronin: "Verifiquei em meus estudos em Porto Alegre que não tinha o temperamento de um apóstolo. E a medicina é um apostolado...”. FIGUEIREDO, Cláudio, op. cit., p. 82.

35 Com tradução de Ilka Labarthe e Raimundo Magalhães Júnior, obra lançada pela José Olympio em I942 e inserida na coleção "Fogos Cruzados", que se propunha a reunir "os maiores romances do mundo". HALLEWELL, Laurence. O livro no Brasil: sua história. 2. ed. rev. e ampl. São Paulo: Edusp, 2005, p. 465. Dessa coleção viria a fazer parte, em I950, o livro A peste, de Albert Camus, em tradução realizada por Graciliano (ele assina o trabalho apenas com suas iniciais G. R.).

36 A partir de maio de I945, os jornais e revistas cariocas davam notícia da chegada ao Brasil da adaptação do livro de Cronin para o cinema, o que ocorreu, de fato, em agosto daquele ano. Lançado nos Estados Unidos em 1944 pela 2oth. Century-Fox, As chaves do reino contou com a direção de John Stahl e roteiro de Joseph Mankiewicz e Nunnally Johnson. No papel principal do padre Francis Chisholm, ganhava destaque a figura de Gregory Peck. Pedro Lima, nas páginas da revista O Cruzeiro, ressaltava que o filme em questão não alcançou o êxito do livro em função do cuidado com a forma literária observado neste e dos descuidos na efabulação patentes naquele. LIMA, Pedro. O cinema não fará mal ao romance. O Cruzeiro, Rio de Janeiro, I5 set. I945, p. 20. 
No romance há um missionário que é uma grande figura, com uma vida extraordinária. É um tipo admirável, que, apesar da sua situação, não se aproveita disso para fazer qualquer sermão contra o leitor incauto. E isso é uma vantagem enorme.

$$
* * *
$$

Com um bom romance, como este, podemo-nos sentir no melhor dos mundos. Contudo, devo esclarecer que o melhor dos mundos não vale um caracol ${ }^{37}$.

37 Segundo Antonio de Moraes Silva, a expressão "não valer um caracol" equivaleria a "não ter valor algum, não ser bom em nada”. SILVA, Antonio de Moraes. Diccionario da lingua portugueza. 6. ed. 2 t. Lisboa: Typographia de Antonio José da Rocha, I858, t. I, p. 404. 


\section{CoIsas da China ${ }^{38}$}

A passagem do Yang-tse-kiang foi um erro estratégico ${ }^{39}$, afirma Chiang Kai-shek ${ }^{40}$. Declarou isso e desapareceu, com certeza foi cuidar de uma estratégia superior, talvez na Ilha Formosa, não se sabe onde ${ }^{4 \mathrm{I}}$.

Mandaram Xangai resistir, sacrificar todos os homens, transformar-se numa segunda Stalingrado ${ }^{42}$. O governo determinou essa energia formidável e transferiu-se cauteloso

38 RAMOS, Graciliano. Coisas da China. Voz Operária, Rio de Janeiro, I6 jun. I949, p. 6 e Io. Para a grafia dos nomes próprios oriundos do chinês, tomaram-se como base, em geral, formas aportuguesadas e, de preferência, o sistema de transliteração Wade-Giles, cujas formas, apesar de não mais em vigor oficialmente na República Popular da China, são mais conhecidas em português brasileiro. Daí, por exemplo, como se verá, a opção por escrever Mao Tsé-tung, e não Mao Zedong (grafia segundo o sistema Pinyin atualmente em vigor).

39 Provável referência à atitude atribuída a Chiang Kai-shek de pedir para que as tropas governamentais não opusessem resistência aos comunistas na linha do rio Yang-tse-kiang. CARROSSEL do Mundo. O Cruzeiro, Rio de Janeiro, I8 jun. I949, p. 29. Em 20 de janeiro de I949, telegrama da United Press já comunicava que o governo nacionalista havia anunciado a evacuação geral da zona ao norte do referido rio, "inclusive dos civis e das dependências públicas”. CHIANG Kai-shek vai abandonar Nanquim. Diário de Notícias, Rio de Janeiro. 2I jan. I949, p. I. Em 23 de abril, a mesma agência dava conta de que Nanquim, então capital da China Nacionalista, que se localizava no delta do Yang-tse-kiang, havia sido abandonada, o que facilitou a travessia do rio em questão pelo Exército Popular de Libertação de Mao Tsé-tung e a tomada, por parte dos comunistas, não só de tal cidade como, depois, de Xangai. ABANDONADA Nanquim ao avanço comunista. Diário Carioca, Rio de Janeiro, 23 abr. I949, p. I.

40 Após a morte de Sun Yat-sen em I925, Chiang Kai-shek assume o comando do Kuomintang, partido nacionalista chinês. A partir desse momento, passa a investir tanto contra os senhores da guerra do Norte quanto contra os comunistas. Com a vitória destes últimos na guerra civil que teve término no final dos anos I940, foge para Taiwan, para onde transfere seu governo nacionalista. Morre nesta ilha em 5 de abril de I975 Cf. Chiang Kai-shek. In: Enciclopédia Escolar Britannica, 20I7. Disponível em: <http://escola.britannica.com. br/ article/480959/Chiang-Kai-shek>. Acesso em: I4 jan. 2017.

4I Num contexto de evacuação de Nanquim, então capital da China Nacionalista, em janeiro de I949, nota da United Press estampada em diferentes jornais brasileiros dava conta de que os "comandados da Armada e da Força Aérea foram transferidos para Formosa e o comando do Exército instalou-se em Cantão”. ORDENADA evacuação geral ao norte do rio Yang-Tsé. A Manhã, Rio de Janeiro, 2I jan. I949, p. 2.

42 Em entrevista, o comandante da guarnição Xangai-Wusung, tenente-coronel Chen Ta Ching, declarara à United Press que suas tropas se preparavam para lutar até a morte e que fariam de Xangai a "Stalingrado de toda a guerra civil chinesa”. RESISTÊNCIA até a morte. Correio da Manhã, Rio de Janeiro, Iํㅡaio I949, p. I. Além disso, pouco antes da publicação deste texto de Graciliano na Voz Operária, o mesmo jornal, ao fazer referência à surpresa com que o "mundo capitalista" recebeu a queda de Xangai ante a ofensiva final realizada pelas tropas comunistas, destacava: "Não tinham afirmado os homens de Chiang Kai-shek que Xangai seria a sua Stalingrado? Não há dúvida que foi às avessas: o seu túmulo, como Stalingrado fora o túmulo do hitlerismo". NORMALIZOU-SE rapidamente a vida em Xangai. Voz Operária, Rio de Janeiro, 7 jun. I949, p. 4. 
para Cantão. Não se sacrificaram todos os homens[,] pelo menos teriam salvação provisória os que se desviaram à pressa, alguns incluídos na lista negra dos $466^{43}$.

O heroísmo imposto a Xangai durou o tempo suficiente para as forças revolucionárias cercarem a cidade, entrarem nela. Os defensores se retiraram: alguns despiram a farda, vestiram roupas civis e jogaram fora as armas ${ }^{44}$. Não tivemos a reedição de Stalingrado.

Covardia? De modo nenhum. Apenas isto: um oficial não pode exigir que os soldados morram a defender uma causa contrária aos interesses deles. Não há disciplina capaz de forjar essa espécie de coragem.

Ultimamente divisões e mais divisões do governo agonizante foram para o campo adversário ${ }^{5}$ - e os canhões dos americanos se voltaram contra os amigos e protegidos destes. [C]orrução, diziam os telegramas, a ve[lha] desonestidade oriental.

Não se provou isso, não há vestígio de suborno em tais adesões, aliás falta aos comunistas meio para corromper. O dinheiro está na América, de lá saíram seis bilhões de dólares e com eles foram comprados os mercenários senhores da guerra. Mau negócio. Evidentemente essas criaturas não valiam soma tão grande. Perdem as batalhas e perdem a cabeça, desmoralizam-se. O melhor general recebe do inimigo o estranho conselho de afastar-se da vida - e mata-se. Quando um chefe deserta assim, não admira que a massa largue o uniforme e levante a bandeira branca. Os sujeitos graúdos - temos o direito de supor isto - não se bandearam voluntariamente, foram arrastados pela tropa. Outros vão recuando. Até onde recuarão? Os soldados não querem lutar por eles.

É interessante notarem os jornais do capitalismo a organização admirável da zona libertada, a contrastar com a desordem anterior. Confissão de impotência.

Os bandidos vermelhos tornaram-se de repente uns indivíduos muito razoáveis, começam a ser adulados. O comunismo chinês - espalham por aí - diferente do comunismo russo, não tem nada com ele. Esperam que do Oriente surja um Tito

43 Em dezembro de I948, telegrama da United Press noticiava que os comunistas tornavam pública uma "lista negra" contendo um rol de altas autoridades do Kuomintang que seriam seus "primeiros objetos de eliminação". O GOVERNO chinês disposto a prosseguir na luta. O Dia, Curitiba, 29 dez. I948, p. I. Pode-se admitir, por hipótese, que Graciliano estivesse fazendo alusão a tal documento. Todavia, enquanto o escritor alagoano faz menção específica a uma "lista negra dos 46", a referida agência de notícias indicava que o conjunto de nomes divulgados pelos partidários de Mao Tsé-tung englobava "milhares de oficiais que servem fielmente às fileiras do Kuomintang". O GOVERNO chinês..., op. cit.

44 Tal imagem da deserção dos soldados nacionalistas já aparecera em texto do jornal Voz Operária referido em nota anterior: "Realmente a situação para os homens de Chiang era tal que, procurando salvar a pele, 'fugiam atirando fora as armas e uniformes e disfarçando-se em trajes civis". NORMALIZOU-SE rapidamente a vida em Xangai, op. cit., p. 4.

45 POMAR, Wladimir. A revolução chinesa. São Paulo: Editora Unesp, 2003, p. 8I. 
amarelo ${ }^{46}$. Os banqueiros terão grande prazer em negociar com esse comunismo de novo tipo.

Americanos e ingleses comportam-se bem por aquelas bandas. E acham direitas as coisas de Xangai para cima. Provavelmente não será necessário o Pacto do Atlântico ${ }^{47}$.

46 Graciliano ecoa especulações que constam dos jornais cariocas em torno de eventuais semelhanças políticas entre o próximo governante da China e o marechal Josip Broz Tito, líder da então Iugoslávia, que, embora tivesse recebido o apoio do Exército Vermelho de Stálin, estabeleceu uma relação conflituosa com a URSS no pós-Segunda Guerra. O Jornal do Brasil de 28 de abril de 1949 destacava que, em muitos pontos, o percurso de Mao Tsé-tung se parecia com o de Tito: "Quinze anos antes de que Tito o fizesse, Mao organizou para uso próprio um exército de cunho pessoal e uma polícia secreta que lhe é incondicionalmente devotada", possibilitando-lhe "tocar e dançar com relativa independência". AL NETO. Nos bastidores do mundo - Mao, Lin e Li. Jornal do Brasil, Rio de Janeiro, 28 abr. I949, p. 5. Algum tempo depois a Tribuna da Imprensa de Carlos Lacerda, em editorial, projetava a pergunta: “Mao Tsé-tung será o Tito do Extremo Oriente?” ( $\mathrm{I}^{\circ}$ mar. I950, p. 4). Theophilo de Andrade propunha questionamento análogo nas páginas da revista O Cruzeiro: "Haverá um Tito na China?” (29 set. I95I, p. 45). Ambas as interrogações especulavam em torno da possibilidade de Mao Tsé-tung ser um instrumento dócil do Kremlin ou adotar uma postura independente, a "ponto de rebelar-se na defesa dos interesses nacionais, como fez Tito, na Iugoslávia”. ANDRADE, Theophilo de. Haverá um Tito na China?. O Cruzeiro, Rio de Janeiro, 29 set. I95I, p. 45.

47 Em junho de I949, ao se referir ao recente "Pacto do Atlântico" (pacto de Defesa do Atlântico Norte assinado, no contexto da Guerra Fria, por doze nações - Bélgica, Canadá, Dinamarca, Estados Unidos, França, Grã-Bretanha, Holanda, Islândia, Itália, Luxemburgo, Noruega e Portugal - em abril de I949, em Washington) Pimentel Gomes, do Correio da Manhã, destacava: “Os Estados Unidos estão certos de se arranjarem bem com o governo de Mao. Que desejam eles? Portas abertas para o seu comércio. Facilidades para a colocação de capitais. Neutralidade no caso de um conflito armado com a União Soviética. Mao, senhor de uma nação de 450 milhões de habitantes, farta de riquezas estáticas, não será - crê-se em Washington - um instrumento cego nas mãos da Rússia”. GOMES, Pimentel. O Pacto do Atlântico. Correio da Manhã, Rio de Janeiro, 5 jun. I949. 


\section{O ATENTADO CONTRA O ESCRITOR WLADIMIR GUIMARÃES ${ }^{48}$}

A diretoria da Associação Brasileira de Escritores enviou o seguinte telegrama ao governador da Bahia, protestando contra o atentado de que foi vítima recentemente o escritor Wladimir Guimarães:

"Contra a violência de que foi vítima o nosso associado Wladimir Guimarães49 a Associação Brasileira de Escritores protesta perante V. Excia., como responsável pela ordem pública garantidora do livre exercício dos direitos cívicos, mormente quando se trata da defesa patriótica de nosso patrimônio de riquezas naturais ou culturais. A punição dos culpados pelo atentado é o único modo consequente de acreditar na legalidade estadual [e] satisfazer anseios de paz e progresso do bravo povo baiano ${ }^{50}$.

Pela Diretoria (As.) - Graciliano Ramos, presidente”.

\section{SOBRE O AUTOR}

THIAGO MIO SALLA é doutor em Letras e Ciências da Comunicação pela Universidade de São Paulo. Atualmente leciona na Escola de Comunicações e Artes (ECA/USP). É autor de Graciliano Ramos e a cultura política: mediação editorial e construção do sentido (Edusp, 20I6) e organizador de Garranchos - textos inéditos de Graciliano Ramos (Record, 20I2).

48 RAMOS, Graciliano. O atentado contra o escritor Wladimir Guimarães. Imprensa Popular, Rio de Janeiro, I6 dez. I95I, p. 9.

49 Segundo matéria publicada pelo jornal Imprensa Popular, dias antes da nota da ABDE assinada por Graciliano, o médico Wladimir Guimarães, então secretário-geral do Movimento Baiano dos Partidários da Paz e diretor da revista de orientação comunista Seiva, havia sido "alvo de brutal atentado contra sua vida por parte do ‘tira' Periandro Cordeiro, conhecido nesta capital [Salvador] como espancador de presos e explorador de mulheres. O policial fez vários disparos contra o médico, não o matando graças à intervenção de populares” ATENTADO contra a vida de um médico baiano. Imprensa Popular, Rio de Janeiro, 29 nov. I95I, p. 3. Ainda segundo o texto, "em vista da onda de protestos contra a brutal agressão, a polícia viu-se obrigada a prender o ‘tira', naturalmente para dar uma satisfação à opinião pública”.

50 Antes da nota da ABDE, alguns deputados da câmara estadual da Bahia (Ebenezer Cavalcanti, Fernando Jatobá, Orlando Spínola, Acioli Borges, Otávio Drumond, Aloísio Short, entre outros) já haviam protestado, na tribuna da casa, contra o atentado sofrido por Wladimir Guimarães. Este recebeu ainda manifestação de solidariedade do Centro de Estudos e Defesa do Petróleo. PROTESTOS contra a agressão ao dr. Wladimir Guimarães. Imprensa Popular, Rio de Janeiro, 5 dez. I95I, p. 2. 


\section{REFERÊNCIAS BIBLIOGRÁFICAS}

A MANHA Literária. A Manha, Rio de Janeiro, Io maio I945, p. 4.

AARÃO REIS, Daniel. O maoismo e a trajetória dos marxistas brasileiros. In: MORAES, João Quartim; AARÃO REIS, Daniel (Org.). História do marxismo no Brasil. V. ı: O impacto das revoluções. Campinas: Editora da Unicamp, 2007, p. I6I-I97.

ABANDONADA Nanquim ao avanço comunista. Diário Carioca, Rio de Janeiro, 23 abr. I949, p. I. AL NETO. Nos bastidores do mundo - Mao, Lin e Li. Jornal do Brasil, Rio de Janeiro, 28 abr. I949, p. 5. ANACLETO, Anastácio [Graciliano Ramos]. Factos e Fitas [III]. In: RAMOS, Graciliano. Garranchos - textos inéditos de Graciliano Ramos. Organização de Thiago Mio Salla. Rio de Janeiro: Record, 20I2, p. 87 ANDRADE, Theophilo de. Haverá um Tito na China?. O Cruzeiro, Rio de Janeiro, 29 set. I95I, p. 45. ATENTADO contra a vida de um médico baiano. Imprensa Popular, Rio de Janeiro, 29 nov. I95I, p. 3. BANDEIRA, Manuel. Memórias de um romancista. A Manha, Rio de Janeiro, 23 ago. 1945, p. 9.

BARBOSA, Juliana Monnerat. Militância política e produção literária no Brasil (dos anos 30 aos 50): as trajetórias de Graciliano Ramos e Jorge Amado e o PCB. 20I0, 403f. Tese (Doutorado em História). Universidade Federal Fluminense, Niterói, RJ, 2010.

CACHIN, Marcel. Mudará a face do mundo. Voz Operária, Rio de Janeiro, 7 jun. I949, p. 5. CARNEIRO, Maria Luiza Tucci; KOSSOY, Boris (Org.). A imprensa confiscada pelo DEOPS: I924-I954. São Paulo: Ateliê Editorial; Imprensa Oficial do Estado de São Paulo; Arquivo do Estado, 2003.

CARROSSEL do Mundo. O Cruzeiro, Rio de Janeiro, I8 jun. I949, p. 29.

CHIANG Kai-shek vai abandonar Nanquim. Diário de Notícias, Rio de Janeiro, 2I jan. I949, p. I. CINEMATOGRAFIA - “Meu reino por uma cozinheira”. Diário de Notícias, Rio de Janeiro, I8 jul. I944, p. II. CRONIN, Archibald Joseph. As chaves do reino. Tradução de Ilka Labarthe e Raimundo Magalhães Júnior. Rio de Janeiro: José Olympio, I942.

EVANGELHO de São Mateus, Português. In: Bíblia sagrada, Tradução de António Pereira de Figueiredo.

Rio de Janeiro, B. L. Garnier, [I864], t. 2, cap. I9, vers. 24, p. 365

FERREIRA, Jorge. Os comunistas e os novos rumos. . In: SIMPÓSIO NACIONAL DE HISTÓRIA, 26., 20II, São Paulo. Anais... Organização de Marieta de Moraes Ferreira. São Paulo: ANPUH, jul. 20пr. Disponível em: <http://www.snh20II.anpuh.org/resources/anais/I4/I3003III93_ARQUIVO_OscomunistaseosNovosRumos.pdf $>$. Acesso em: 27 jan. 2017.

FIGUEIREDO, Cláudio. Entre sem bater: a vida de Apparício Torelly, o Barão de Itararé. Rio de Janeiro:

Casa da Palavra, 2012.

GOMES, Pimentel. O Pacto do Atlântico. Correio da Manhã, Rio de Janeiro, 5 jun. I949.

GRACILIANO Ramos ingressa no Partido Comunista do Brasil e participa da luta pela Constituinte.

Tribuna Popular, Rio de Janeiro, I8 ago. I945, p. I-2.

HALLEWELL, Laurence. O livro no Brasil: sua história. 2 ed. rev. e ampl. São Paulo: Edusp, 2005.

KONDER, Leandro. Barão de Itararé. São Paulo: Brasiliense, I983.

LIMA, Pedro. O cinema não fará mal ao romance. O Cruzeiro, Rio de Janeiro, I5 set. I945, p. 20.

MORAES, Dênis de. O velho Graça: uma biografia de Graciliano Ramos. São Paulo: Boitempo, 2012.

NO MUNDO da Elegância - Uma nova seção de A Manha será confiada ao nosso companheiro Graciliano

Ramos, assim que este regresse de uma viagem ao Chile. A Manha, Rio de Janeiro, 24 maio I945, p. 2. NORMALIZOU-SE rapidamente a vida em Xangai. Voz Operária, Rio de Janeiro, 7 jun. I949, p. 4. PEREIRA, José Mario (Org.). José Olympio - o editor e sua Casa. Rio de Janeiro: Sextante, 2008. POMAR, Wladimir. A revolução chinesa. São Paulo: Editora Unesp, 2003.

O EXEMPLO da China frutifica em toda a Âsia Sul-Oriental. Voz Operária, Rio de Janeiro, I5 jul. I949, p. 6. 
O GOVERNO chinês disposto a prosseguir na luta. O Dia, Curitiba, 29 dez. I948, p. I.

ORDENADA evacuação geral ao norte do rio Yang-Tsé. A Manhã, Rio de Janeiro, 2I jan. I949, p. 2.

PROTESTOS contra a agressão ao dr. Wladimir Guimarães. Imprensa Popular, Rio de Janeiro, 5 dez. I95I, p. 2.

RESISTÊNCIA até a morte. Correio da Manhã, Rio de Janeiro, Io maio I949, p. I.

RAMOS, Graciliano. O melhor dos mundos. A Manha (do Barão de Itararé), Rio de Janeiro, I5 ago. I945, p. 7. . A um sifilítico. A Manha, Rio de Janeiro, 5 set. I945, p. Io. . Coisas da China. Voz Operária, Rio de Janeiro, I6 jun. I949, p. 6 e Io . O atentado contra o escritor Wladimir Guimarães. Imprensa Popular, Rio de Janeiro, I6 dez. I95I, p. 9. . Memórias do cárcere. 4 v. Rio de Janeiro: José Olympio, I953. . Linhas tortas. 2I. ed. Rio de Janeiro: Record, 2005. . Garranchos - textos inéditos de Graciliano Ramos. Organização de Thiago Mio Salla. Rio de Janeiro: Record, 2012.

RAMOS, Ricardo. Graciliano: retrato fragmentado. São Paulo: Siciliano, I992.

SALLA, Thiago Mio. "A Bíblia sagrada de Graciliano Ramos: a leitura e a glosa do texto religioso realizadas pelo autor de Vidas secas”. Livro, São Paulo, Núcleo de Estudos do Livro e da Edição (ECA/USP), v. 4, 20I4, p. I4I-I67.

SHAKESPEARE, William. King Richard III. Edited by Antony Hammond. Londres, Nova York: Routledge, I990.

SILVA, Antonio de Moraes. Diccionario da lingua portugueza. 6. ed. 2 t. Lisboa: Typographia de Antonio José da Rocha, I858, t. I, p. 404. 